\title{
Kelola
}

Jurnal Manajemen Pendidikan

Magister Manajemen Pendidikan

e-ISSN 2549-9661

FKIP Universitas Kristen Satya Wacana

Volume: 4, No. 2, Juli-Desember 2017

jurnalkelola@gmail.com

Halaman: 220-230

\section{Pengaruh Kreativitas dalam Peningkatan Kompetensi Kepemimpinan Alumni Magister Manajemen Pendidikan Pada Kurikulum Berbasis Kompetensi}

\author{
Krisma Widi Wardani \\ Pendidikan Guru Sekolah Dasar Universitas Kristen Satya Wacana \\ krisma.widi@staff.uksw.edu
}

\begin{abstract}
This study aims to find out: 1) whether or not the leadership quality of the alumni of MMP FKIP UKSW is affected by creativity and curriculum; and 2) the determinants of the alumni's leadership level: creativity or curriculum factor. The participants of this research are those who have graduated (alumni) from MMP FKIP UKSW Salatiga, working in Temangung regency. There were as many as 35 alumni in 2014/2015 selected to join this research. The data was collected using self-rating scale consisting of 32 items that have been tested valid and reliable, then it was reduced to 3 variables. The analysis process was undertaken by using SPSS 24 assisted analysis technique. The result of this research showed that curriculum have nothing to do with the level of leadership. Meanwhile, alumni's leadership level is significantly determined by the creativity. This finding is very important for the aspect of course quality improvement management that supposed to be conducted by professional lecturers. MMP FKIP UKSW refines its learning activities on creativity-based lectures which will bring positive influence on leadership level.
\end{abstract}

Keywords: Creativity, Curriculum Relevance, Leadership

\section{Article Info}


Pengaruh Kreativitas dalam Peningkatan Kompetensi Kepemimpinan Alumni ... | Krisma W. Wardani

\section{PENDAHULUAN}

Kata kunci atau faktor utama kepemimpinan adalah proses mempengaruhi (Yukl, 2010). Kepemimpinan dipandang sebagai faktor yang sangat penting untuk efektivitas organisasi, bahkan juga mempengaruhi hampir semua kehidupan manusia (Handoyo, S., 2011). Kepemimpinan menurut Bush (2008) "I mean influencing others actions in achieving desirable ends", kepemimpinan ialah mempengaruhi tindakan orang lain untuk mencapai tujuan akhir yang diharapkan. Kepemimpinan merupakan salah satu faktor penting dalam mencapai tujuan organisasi (Robbins, 1996).

Kepemimpinan, sampai hari ini tetap dianggap sangat penting; Goleman, D., R. Boyatzis, \& McKee (2003) menemukan bahwa ada hubungan antara keberhasilan dan kegagalan organisasi dengan kepemimpinan, dengan adanya kecerdasan emosional pemimpin mampu mengelola kekuasaan dan meningkatkan kinerjanya secara optimal serta menularkan kepada bawahannya. Seorang pemimpin hanya dapat melakukan kepemimpinannya apabila memiliki kekuasaan, namun begitu pengaruh kekuasaan dapat memberi manfaat atau justru menyengsarakan (Usman, H., 2016). Frost (2003) menekankan bahwa akibat krisis kepemimpinan, banyak orang yang menderita, yang mengalami burn-out, yang tidak dapat menikmati hidup dalam pekerjaannya, serta banyak biaya yang dikeluarkan untuk mengobati sakit emosional di tempat kerja. Berdasarkan pendekatan sifat-sifat pemimpin menyebutkan bahwa pemimpin itu dilahirkan bukan diciptakan (leader are born, not built), artinya seseorang telah membawa bakat kepemimpinan sejak dilahirkan bukan dididik dan dilatih. Teori itu disebut teori The Great Man yang ada sejak zaman Yunani Kuno dan Roma (Usman, H., 2016). Namun demikian kepemimpinan yang efektif terletak pada seberapa jauh sifat pemimpin dapat mengatasi keadaan yang dihadapinya. Ada kebutuhan besar pada saat ini untuk melakukan pendidikan kepemimpinan untuk generasi yang akan datang, termasuk kepemimpinan melalui institusi pendidikan tinggi.

Pendidikan tinggi mempunyai karakteristik khas sehingga membutuhkan kepemimpinan tertentu (Handoyo, S., 2011). Menurut Notohamidjojo, O., (2011; 14) salah satu tugas Perguruan Tinggi Guru Indonesia dalam masyarakat yaitu mendidik pemimpinpemimpin akademis, sebab fungsi perguruan tinggi itu tempat calon pemimpin. Seseorang yang menduduki jabatan pemimpin dalam manajerial suatu organisasi (termasuk pendidikan tinggi) mempunyai peranan penting. Peran-peran tersebut yaitu: sebagai katalisator, sebagai fasilitator, sebagai pemecah masalah, sebagai penghubung sumber, dan sebagai komunikator. Keberhasilan kepemimpinan seseorang dapat diukur atau ditandai oleh empat hal, yaitu : moral, disiplin, jiwa korsa (esprit de corps) dan kecakapan (Faisal Burhanudin, 2012/2013). Kepemimpinan masa depan adalah kepemimpinan yang memiliki sifat jujur, berani, visioner, kompeten, penginspirasi, dan meberdayakan (Usman, H., 2016). Mengingat demikian penting peran kepemimpinan, apalagi program studi Manajemen Pendidikan, maka salah satu bentuk/ indikator keberhasilan program studi yang bersangkutan adalah seberapa tinggi kadar kepemimpinan mahasiswa lulusannya; sehingga seluruh sarana dan prasarana diupayakan untuk mendukung capaian mahasiswa selagi perkuliahan berlangsung sebagai basis manajemen program studi yang bersangkutan. Permasalahannya, hingga kini belum ditemukan seberapa besar pengaruh kreativitas yang menentukan kualitas kepemimpinan alumninya.

Kepemimpinan menurut Hughes, R., Ginnett, R., \& Curphy, G. (2002) berkenaan dengan keberanian mengambil risiko dengan 
Kelola: Jurnal Manajemen Pendidikan, Vol. 4, No. 2, Juli-Desember 2017

perhitungan yang matang, dinamika, kreativitas, inovasi, perubahan dan visi. Pemimpin itu harus memiliki beberapa kelebihan, yaitu: 1) Kapasitas: kecerdasan, kewaspadaan, kemampuan berbicara atau verbal facility, keaslian, kemampuan menilai.

2) Prestasi/achievement: gelar kesarjanaan, ilmu, pengetahuan, peroleha dalam olag raga dan atletik dan lain lain. 3) Tanggung jawab: mandiri, berinisiatif, tekun, ulet, percaya diri, agresif, dan punya hasrat untuk unggul. 4) Partisipasi: aktif, memiliki sosiabilitas tinggi, mampu bergaul, kooperatif atau suka bekerja sama, mudah menyesuaikan diri, punya rasa humor. 5) Status: meliputi kedudukan sosialekonomi yang cukup tinggi, populer, tenar. Seorang pemimpin harus memiliki ciri yang unggul, yaitu: 1) Kekuatan 2) Stabilitas emosi 3) Pengetahuan tentang relasi insani 4) Kejujuran 5) Objektif 6) Dorongan hati 7) Keterampilan berkomunikasi 8) Kemampungan mengajar 9) Keterampilan sosial 10) Kecakapan teknis dan kecakapan manajerial (G. R Terry dalam Kartini Kartono, 2006). Kepimpinan adalah kemampuan seseorang mempengaruhi orang lain dalam melaksanakan tugas mencapai tujuan yang telah ditetapkan. Adapun indikator kepemimpinan adalah: memberikan dukungan, mengembangkan, memberikan pengakuan, memberikan imbalan, mengelola konflik dan membangun jaringan kerja (Wibowo, B., Machfudz, M., \& Sunaryo, H., 2015) [Y].

Kurikulum adalah seperangkat rencana dan pengaturan mengenai tujuan, isi, dan bahan ajar serta cara yang digunakan sebagai pedoman penyelenggaraan kegiatan pembelajaran untuk mencapai tujuan Pendidikan Tinggi (Pasal 35 Bagian 9 UU No. 12 Tahun 2012 tentang Pendidikan Tinggi). Kurikulum pendidikan tinggi adalah seperangkat rencana dan pengaturan mengenai isi maupun bahan kajian dan pelajaran serta cara penyampaian dan penilaiannya yang digunakan sebagai pedoman penyelenggaraan kegiatan belajar-mengajar di perguruan tinggi (Pasal 1 Butir 6 Kepmendiknas No. 232/U/2000 tentang Pedoman Penyusunan Kurikulum Pendidikan Tinggi dan Penilaian Hasil Belajar Mahasiswa). Kurikulum pendidikan tinggi dikembangkan oleh Perguruan Tinggi yang bersangkutan dengan mengacu Standar Nasional Pendidikan untuk setiap program studi. Kurikulum tidak hanya gagasan pendidikan tetapi juga termasuk seluruh program pembelajaran yang terencana dari suatu institusi pendidikan. Kurikulum merupakan wujud materi yang diajarkan dalam proses pembelajaran (Rohman, A., 2011, 168). Pada saat sekarang istilah kurikulum memiliki empat dimensi, satu dimensi dengan dimensi lainnya saling berhubungan. Keempat dimensi kurikulum tersebut yaitu: (1) kurikulum sebagai suatu ide/gagasan; (2) kurikulum sebagai suatu rencana tertulis yang sebenamya merupakan perwujudan dari kurikulum sebagai suatu ide; (3) kurikulum sebagai suatu kegiatan yang sering pula disebut dengan istilah kurikulum sebagai suatu realita atau implementasi kurikulum. Secara teoretis dimensi kurikulum ini adalah pelaksanaan dari kurikulum sebagai suatu rencana tertulis; dan (4) kurikulum sebagai suatu hasil yang merupakan konsekuensi dari kurikulum sebagai suatu kegiatan. Kurikulum dalam pendidikan formal memiliki peranan yang sangat strategis dan menentukan pencapaian tujuan pendidikan. Salah satu tugas pendidikan yaitu mempengaruhi dan membina perilaku mahasiswa sesuai dengan nilai-nilai sosial yang hidup di lingkungan masyarakatnya. Peranan ini menekankan bahwa kurikulum harus mampu mengembangkan sesuatu yang baru sesuai dengan perkembangan yang terjadi dan kebutuhan-kebutuhan masyarakat pada masa sekarang dan masa mendatang. Kurikulum harus mengandung hal-hal yang dapat membantu setiap mahasiswa mengembangkan semua potensi yang ada pada dirinya untuk memperoleh pengetahuan- 
pengetahuan baru, kemampuan-kemampuan baru, serta cara berpikir baru yang dibutuhkan dalam kehidupannya $\left[\mathrm{X}_{1}\right]$.

Menurut Santrock dalam Sujiono (2010: 38) kreativitas adalah kemampuan untuk memikirkan sesuatu dengan cara-cara yang baru dan tidak biasa serta melahirkan suatu solusi yang unik terhadap masalahmasalah yang dihadapi. Slameto (2010) menjelaskan bahwa kreativitas berhubungan dengan penemuan sesuatu, mengenai hal yang menghasilkan sesuatu yang baru dengan menggunakan sesuatu yang telah ada. Sesuatu yang baru ini dapat berupa perbuatan atau tingkah laku, bangunan, dan lain-lain. Kreativitas mengandung pengertian, yaitu: menciptakan sesuatu yang asalnya tidak ada, hasil kerja sama masa kini untuk memperbaiki masa lalu dengan cara yang baru, dan menghilangkan sesuatu untuk menciptakan sesuatu yang lebih sederhana dan lebih baik.

Kreativitas seseorang adalah kemampuan untuk menciptakan konsep, gagasan atau cara-cara baru dalam usahanya memecahkan masalah. Kreativitas diukur berdasarkan pada keterbukaan terhadap pengalaman baru, kebebasan dalam berekspresi, minat terhadap aktivitas kreatif, fleksibel dalam berfikir serta percaya terhadap gagasan sendiri sehingga menimbulkan motivasi untuk mengembangkan diri. Kreativitas mahasiswa adalah kemampuan untuk menciptakan konsep, gagasan atau caracara baru dalam usahanya memecahkan masalah. Dengan adanya kreativitas, diharapkan mahasiswa dapat mengembangkan kemampuan dan keterampilan sebagai alternatif pemecahan masalah apabila belum mendapatkan kesempatan bekerja baik di instansi pemerintahan maupun swasta, dan mampu memilih pekerjan yang sesuai dengan keinginannya.

Ciri-ciri individu dengan potensi kreatif adalah sebagai berikut: 1) hasrat keingintahuan yang cukup besar. 2) bersikap terbuka terhadap pengalaman baru. 3) panjang akal. 4) keinginan untuk menemukan dan meneliti. 5) cenderung lebih menyukai tugas yang berat dan sulit. 6) cenderung mencapai jawaban yang luas dan memuaskan. 7) memiliki dedikasi bergairah serta aktif dalam melaksanakan tugas. 8) berfikir fleksibel. 9) menanggapi pertanyaan yang diajukan serta cenderung memberi jawaban yang lebih banyak. 10) kemampuan membuat analisis dan sitesis. 11) memiliki semangat bertanya serta meneliti. 12) memiliki daya abstraksi yang cukup baik. 13) memiliki latar belakang membaca yang cukup luas (sud dalam slameto, 2003).

Dyer, J., Gregersen, H., \& Christensen, C. M. (2011) menyatakan bahwa dua pertiga dari kemampuan kreativitas seseorang diperoleh melalui pendidikan, dan sisanya berasal dari genetik. Kemampuan kreativitas diperoleh melalui mengamati (observing), menanya (questioning), mencoba (experimenting), menalar (associating), dan membentuk jaringan (networking) (Untayana, J. R., \& Harta, I., 2016). Faktor yang mempengaruhi kreativitas yaitu: 1) Waktu, sebaiknya jangan terlalu banyak diatur, 2) Kesempatan, kesempatan untuk menyendiri diperlukan guna mengembangkan kehidupan imajinatif yang kaya. 3) Dorongan, didorong untuk kreatif dan bebas dari ejekan/kritikan. 4) Sarana, harus disediakan guna merangsang dorongan eksperimentasi dan eksplorasi yang merupakan unsur penting dari kreativitas. 5) Lingkungan yang merangsang, lingkungan rumah dan sekolah harus merangsang kreativitas dengan memberikan bimbingan dan dorongan untuk menggunakan sarana yang akan mendorong kreativitas. 6) Hubungan orang tua dan anak yang tidak posesif, orang tua yang tidak terlalu melindungi/posesif terhadap anak mendorong anak untuk mandiri dan percaya diri yang merupakan dua kualitas yang sangat mendukung kreativitas. 7) Cara mendidik anak, mendidik anak demokratis 
Kelola: Jurnal Manajemen Pendidikan, Vol. 4, No. 2, Juli-Desember 2017

akan menyebabkan anak menjadi kreatif dari pada cara mendidik anak secara otoriter. 8) Kesempatan untuk memperoleh pengetahuan, semakin banyak pengetahuan yang dapat diperoleh anak semakin baik dasar untuk mencapai hasil yang kreatif (Elisabert Hurlock yang diterjemahkan oleh Meitasari Tjandrasa, 2002). Faktor yang mempengaruhi kreativitas antara lain: adanya waktu, kesempatan menyendiri, dorongan dari orang lain, sarana, lingkungan yang mendukung dan kondusif, hubungan antara anak dengan orang tua, cara mendidik anak dan kesempatan untuk memperoleh pengetahuan melalui melalui kegiatan mengamati (observing), menanya (questioning), mencoba (experimenting), menalar (associating), dan membentuk jaringan (networking) [ $\left.\mathrm{X}_{2}\right]$.

Penelitian ini

mencoba

mendeskripsikan seberapa tinggi kadar kepemimpinan alumni yang dikembangkan melalui implementasi kurikulum 2013 berbasis KBK Program Manajemen Pendidikan UKSW Salatiga, dan menemukan variabel manakah yang menjadi penentu kadar kepemimpinan alumni yang dimaksud, di antaranya variabel: kreativitas dan relevansi kurikulum 2013 berbasis KBK. Jawaban atas permasalahan ini sangat penting bagi manajemen peninkatan mutu pendidikan berbasis penelitian; yang selama ini luput dari desain manajemen mutu PT.

Dalam perspektive manajemen pendidikan, kualitas kepemimpinan alumni merupakan salah satu indikator mutu pendidikan tinggi yang sangat penting; oleh karena itu perlu diupayakan secara terus menerus. Masalah dalam penelitian ini adalah: 1) seberapa tinggi tingkat kepemimpinan alumni yang dikembangkan melalui kurikulum 2013 berbasis KBK Program Manajemen Pendidikan UKSW Salatiga selama ini, dan 2) diantara variabel: kurikulum 2013 berbasis KBK dan kreativitas, manakah yang menjadi penentu tingkat kepemimpinan alumni yang dimaksud? Jawaban atas permasalahan ini sangat penting bagi manajemen peningkatan mutu pendidikan berbasis penelitian; yang selama ini sering luput dari desain manajemen PT.

\section{METODE PENELITIAN}

Penelitian ini dilakukan berdasarkan penilaian dari para alumni yang telah lulus Program Magister Manajemen Pendidikan UKSW. Populasi dari penelitian ini adalah alumni MP UKSW Salatiga yang tersebar di 5 wilayah yakni di Kabupaten Demak, Grobogan, Kendal, Semarang dan Temanggung. Teknik pengambilan sampel menggunakan teknik cluster sampling. Menurut Lusiana, N., Andriyani, R., \& Megasari, M. (2015) cluster sampling merupakan teknik untuk menentukan sampel bila objek yang diteliti atau sumber data sangat luas maka pengambilan sampelnya berdasarkan daerah yang telah ditetapkan. Daerah yang telah ditetapkan yaitu Kabupaten Temanggung yang terdiri dari 36 orang. Berdasarkan rumusan masalah yang diajukan, ternyata penelitian ini adalah penelitian kuantitatif inferensial. Penelitian kuantitatif mengungkapkan hubungan inferensial antara dua atau lebih variabel yang bisa menjelaskan gejala, yang meneliti pengaruh variabel $\mathrm{X}_{1}$ (relevansi kurikulum), terhadap Y (pengembangan kompetensi kepemimpinan alumni Program Manajemen Pendidikan UKSW Salatiga); dan kemudian menemukan variabel moderator $\mathrm{X}_{2}$ yaitu kreativitas. Penelitian ini dilakukan pada semester 2 2016/2017.

\section{Hipotesis statistik}

Dalam skala ordinal, variabel relevansi kurikulum, terdapat satu tingkat yang dominan di antara empat kategori: rendah, sedang, tinggi dan sangat tinggi. Di antara variabel independen, berpengaruh positif dan signifikan terhadap tingkat kepemimpinan alumni. Dengan kata lain, koefisien regresi 
Pengaruh Kreativitas dalam Peningkatan Kompetensi Kepemimpinan Alumni ... | Krisma W. Wardani

prediktor penentu $\left(b_{1}\right)$ adalah positif dan signifikan. Hipotesis statistik yang diajukan adalah:

$\mathrm{H}_{0}: \mathrm{b}_{1}=0$ (tidak ada pengaruh kreativitas terhadap tingkat kepemimpinan alumni)

$\mathrm{H}_{1}: \mathrm{b}_{1} \neq 0$ (ada pengaruh kreativitas terhadap tingkat kepemimpinan alumni)

Dampak dari prediktor secara tunggal maupun ganda yang ditemukan dapat diketahui dengan melihat nilai $b$ dalam variabel yang bersangkutan.

Selain itu, pentingnya nilai $b$ akan diuji dengan t-test. Signifikansi $T$ dapat terlihat pada nilainya. Jika $b$ positif, dan $t$ signifikan pada tingkat kesalahan kurang dari 0,05, hipotesis $\left(\mathrm{H}_{1}\right)$ akan diterima.

\section{Instrumen dan Teknik Analisis Data}

Data penelitian ini adalah data kuantitatif dalam bentuk angka; Data ordinal adalah data yang dinyatakan dalam bentuk kategori dan/ peringkat. Skala ordinal yang digunakan adalah skala peringkat yang terdiri dari pernyataan dan pilihan jawaban yang berjenjang (rendah, sedang, tinggi dan sangat tinggi) sesuai dengan tujuan pengukuran. Data dikumpulkan melalui skala self-rating yang terdiri dari 32 item yang telah terbukti valid dan reliabel; Skor validitas 0,314 sampai 0,506, dengan indeks reliabilitas Cronbach Alpha $=0,632$. Data setiap variabel dianalisis dengan menggunakan distribusi frekuensi dan dilanjutkan dengan analisis regresi linier ganda dengan Model Entered. Sebelum dianalisis regresi linier ganda dengan SPSS, data ordinal dikonvert kedalam data interval terlebih dulu, baru selanjutnya, peneliti mengembangkan model hubungan (model kausal). Pola-pola berpengaruhnya variabel independen terhadap variabel terikat diuji dengan uji $\mathrm{F}$ pada tingkat 0,05 . Perhitungan ini dilakukan dengan SPSS versi 24. Dalam pengujian model, koefisien determinan dari variabel independen terhadap variabel dependen dihitung. Hasil perhitungan koefisien determinasi dari variabel independen dan moderator dalam penelitian ini terhadap variabel dependen sebesar koefisien adjusted $\mathrm{R}^{2}$. Jika signifikansi $\mathrm{r}$ kurang dari atau sama dengan 0,05, maka model ini dinyatakan signifikan, karena $\mathrm{X}$ dan Moderator mempengaruhi Y, sebesar koefisien adjusted $\mathrm{R}^{2}$.

\section{HASIL PENELITIAN DAN PEMBAHASAN}

\section{Hasil Penelitian}

Setelah data dijaring menggunakan self-rating scale yang terdiri dari 32 items yang direduksi menjadi 3, selanjutnya dianalisis secara descriptive berbantu program SPSS for windows version 24 diperoleh dalam bentuk tabel 1 berikut ini.

Tabel 1. Indeks Variabel Penelitian

\begin{tabular}{lccccc} 
& Mean & Median & Std. Deviation & Minimum & Maximum \\
\hline Kurikulum $\left(\mathrm{X}_{1}\right)$ & 3,5000 & 3,5000 &, 50709 & 3,00 & 4,00 \\
Kreativitas $\left(\mathrm{X}_{2}\right)$ & 3,3611 & 3,0000 &, 48714 & 3,00 & 4,00 \\
Kepemimpinan $(\mathrm{Y})$ & 3,5000 & 3,5000 &, 50709 & 3,00 & 4,00 \\
\hline
\end{tabular}

Berdasarkan hasil analisis deskriptif tersaji pada tabel 1 di atas, sebagian besar responden memandang relevansi kurikulum 2013 berbasis KBK Magister Manajemen Pendidikan $\left(\mathrm{X}_{1}\right)$ pada aras tinggi cenderung sangat tinggi, Kreativitas $\left(\mathrm{X}_{2}\right)$ pada aras tinggi, dan kepemimpinan alumni (Y) pada aras tinggi cenderung sangat tinggi. 
Kelola: Jurnal Manajemen Pendidikan, Vol. 4, No. 2, Juli-Desember 2017

\section{Hasil uji hipotesis}

Analisis selanjutnya adalah uji hipotesis untuk mengetahui apakah kedua variabel bebas yaitu relevansi kurikulum $\left(\mathrm{X}_{1}\right)$ dan kreativitas $\left(\mathrm{X}_{2}\right)$ berpengaruh terhadap kepemimpinan alumni Manajemen Pendidikan UKSW Salatiga (Y). Jika benar, berapa besar pengaruhnya? Hasil analisis regresi ada pada 2 tabel berikut ini.

Tabel 2. Model Summary

\begin{tabular}{ll|r|r|r}
\hline Model & R & R Square & Adjusted R Square & \multicolumn{2}{c}{$\begin{array}{c}\text { Std. Error of the } \\
\text { Estimate }\end{array}$} \\
\hline 1 &, $752^{\mathrm{a}}$ &, 565 &, 552 &, 33925 \\
\hline
\end{tabular}

a. Predictors: (Constant), Kreativitas

Berdasarkan hasil uji regresi pengaruh kreativitas terhadap kepemimpinan alumni seperti tersaji pada tabel 2 di atas, ternyata diperoleh $\mathrm{R}=0,752$ dan dari hasil penghitungan diperoleh Adjusted $R$ square 0,552 berarti kreativitas memberikan pengaruh terhadap kepemimpinan sebesar 55,20\%. Sebagai variabel independen atau prediktor, kreativitas berpengaruh terhadap kepemimpinan alumni.

Tabel 3. ANOVA ${ }^{\mathrm{a}}$

\begin{tabular}{|c|c|c|c|c|c|c|}
\hline \multicolumn{2}{|c|}{ Model } & Sum of Squares & \multirow[t]{2}{*}{ Df } & Mean Square & \multirow{2}{*}{$\frac{\mathbf{F}}{44,200}$} & \multirow{2}{*}{$\frac{\text { Sig. }}{, 000^{\mathrm{b}}}$} \\
\hline 1 & Regression & 5,087 & & 5,087 & & \\
\hline & Residual & 3,913 & 34 &, 115 & & \\
\hline & Total & 9,000 & 35 & & & \\
\hline
\end{tabular}

a. Dependent Variable: Kepemimpinan

b. Predictors: (Constant), Kreativitas

Berdasarkan tabel 3 Anova seperti di atas, ternyata diperoleh $F=44,200$ pada tingkat signifikansi 0,000 ; Besarnya tingkat signifikansi 0,000 ini lebih kecil dari 0,05 yang artinya bahawa kreativitas berpengaruh terhadap kepemimpinan. Dengan demikian kreativitas terbukti berperan meningkatkan kepemimpinan alumni Manajemen Pendidikan UKSW Salatiga (Y). Selanjutnya untuk mengetahui peran kreativitas, dapat diperiksa pada tabel 5 berikut ini.

Tabel 4. Coefficients ${ }^{a}$

\begin{tabular}{|c|c|c|c|c|c|c|}
\hline \multirow{2}{*}{\multicolumn{2}{|c|}{ Model }} & \multicolumn{2}{|c|}{ Unstandardized Coefficients } & \multirow{2}{*}{$\begin{array}{l}\text { Standardized } \\
\text { Coefficients } \\
\text { Beta }\end{array}$} & \multirow[b]{2}{*}{$\mathbf{t}$} & \multirow[b]{2}{*}{ Sig. } \\
\hline & & B & Std. Error & & & \\
\hline \multirow[t]{2}{*}{1} & (Constant) &, 870 & ,400 & & 2,176 &, 037 \\
\hline & Kreativitas &, 783 & 118 &, 752 & 6,648 & ,000 \\
\hline
\end{tabular}

a. Dependent Variable: Kepemimpinan

Ketika semakin tinggi $\mathrm{x} 2$ / kreativitasnya maka berpengaruh signifikan pada semakin tingginya kepemimpinan alumni.
Masing-masing Dapat dilihat dari koefisien dari kreativitas 
Berdasarkan tabel 5 Coefisien $^{\mathrm{a}}$ kepemimpinan alumni seperti di atas, ternyata diperoleh kreativitas dengan $\mathrm{T}$ sebesar 6,648 dengan signifikansi 0,000, dengan demikian $\mathrm{H}_{1}$ yang menyatakan ada pengaruh Kreativitas (X) terhadap tingkat kepemimpinan alumni Program Manajemen Pendidikan UKSW Salatiga dapat diterima. Besarnya pengaruh kreativitas terhadap tingkat kepemimpinan alumni $=55,20 \%$. Ketika semakin tinggi variabel kreativitasnya $\left(\mathrm{X}_{2}\right)$ maka berpengaruh signifikan pada semakin tingginya kepemimpinan alumni.

\section{Pembahasan}

Hasil penelitian menunjukkan bahwa tingkat kreativitas berada pada aras tinggi cenderung sangat tinggi. Pengaruh kreativitas terhadap tingkat kepemimpinan alumni menjadi sangat berarti $(55,20 \%)$. Walaupun begitu masih ada beberapa hal yang perlu diperhatikan dan dijadikan masukan untuk penyempurnaan dalam pengelolaan perkuliahan dalam rangka pengembangan kepemimpinan alumni Program Manajemen Pendidikan UKSW Salatiga. Penelitian ini juga menunjukkan bahwa meskipun kurikulum diperbaiki atau tidak, tidak akan memberi pengaruh pada kepemimpinan mahasiswa sehingga diperlukan tindakan manajemen yang tepat sasaran.

\section{Perlunya Peningkatan kreativitas dalam kegiatan perkuliahan}

Kolb, A.Y., \& Kolb D.A., (2009) menuliskan bahwa belajar adalah sebuah proses adaptasi holistik. Belajar bukan hanya sebuah pengertian, tetapi di dalamnya mencakup fungsi yang saling berkaitan dari seseorang-pikiran, perasaan, pemahaman, dan perilaku. Hal tersebut meliputi model adaptasi khusus lainnya dari metode ilmiah untuk pemecahan masalah, pembuatan keputusan dan kreativitas. Proses perkuliahan yang dijalankan seorang dosen adalah sebuah proses yang memadukan semua pihak, termasuk mahasiswa, dalam sebuah aktivitas interaktif diantara mereka dengan mentransformasi sejumlah sumber daya agar pencapaian tujuan pembelajaran berjalan efektif.

Perkuliahan yang bermutu adalah perkuliahan yang didasarkan pada upaya pemenuhan harapan semua pengguna layanan perkuliahan baik internal ataupun eksternal. Hill, Lomas, dan MacGregor (2003) melaporkan dalam penelitian mereka bahwa persepsi mahasiswa tentang pembelajaran berkualitas mencakup pengalaman yang membantu mereka menghubungkan teori dengan dunia nyata, tugas yang relevan dengan tempat kerja nyata, diskusi yang mengarah ke perspektif pemikiran baru, dan kurikulum yang memperhitungkan pengalaman kelompok mahasiswa dan memberikan nilai tambah kepada mahasiswa. Hill juga melaporkan munculnya tiga strategi pengajaran utama yang dinilai tinggi oleh mahasiswa di pendidikan tinggi: strategi dan teknik pengiriman di kelas; Umpan balik kepada mahasiswa di kelas dan dalam tugas; dan hubungan dengan mahasiswa di kelas.

Sumbangan pendidikan tinggi yang paling nyata adalah lulusannya. Kualitas lulusan, dari aspek pengetahuan, ketrampilan, dan sikapnya, akan sangat menentukan perkembangan bangsa dan kesejahteraan masyarakat. Mahasiswa adalah pemimpin masa depan bangsa. Dalam konteks itu, tantangan pendidikan tinggi adalah membantu mahasiswa untuk mengembangkan bakat khusus dan sikap mereka yang memungkinkan mereka untuk menjadi pemimpin dan agen perubahan sosial yang efektif. Disamping melalui modeling dari pemimpin, pengembangan kepemimpinan mahasiswa melalui program kurikuler dan kokurikuler (DirjenDikti, 2004a).

Kegiatan perkuliahan yang dilakukan yang mendukung pengembangan kreativitas antara lain kegiatan mengamati (observing), 
Kelola: Jurnal Manajemen Pendidikan, Vol. 4, No. 2, Juli-Desember 2017

menanya (questioning), mencoba (experimenting), menalar (associating), dan membentuk jaringan (networking) yang direncanakan oleh dosen bersama mahasiswa, hal tersebut sejalan dengan Dyer, J., Gregersen, H., \& Christensen, C. M. (2011). Kolb, A.Y., \& Kolb D.A., (2009) menjelaskan bagaimana Experiential Learning Theory dapat berfungsi sebagai kerangka kerja yang bermanfaat untuk merancang dan mengimplementasikan program manajemen pendidikan. Dalam pendidikan yang lebih tinggi, proses belajar dari pengalaman terjadi dimana-mana, dan hadir dalam kehidupan dimanapun sepanjang waktu. Hal tersebut berarti proses pengembangan kreativitas dapat ditterapkan melalui pembelajaran yang berbasis masalah, berpikir kritis, pendekatan kelompok. Melalui pembelajaran tersebut pelaksanaannya tidak hanya terikat dalam pembelajaran di kelas semata namun juga di luar kelas. Banyak gaya pembelajaran individual dibentuk oleh struktur pengetahuan sosial dan melalui tindakan-tindakan kreatif perorangan. Maka dari itu, perkuliahan yang bermutu haruslah mampu menjawab semua keinginan, kebutuhan, dan kepuasan semua pelanggan.

Ada beberapa karakteristik dalam menerapkan manajemen mutu terpadu dalam perkuliahan. Karakteristik perkuliahan seperti ini bisa diadaptasi dari karya Parker dkk. (Jabar, C. S. A., \& Pelanggan, G. S. H.) yaitu: berorientasi pada mahasiswa, partisipasi/team, perbaikan berkelanjutan, berorientasi pada proses, keputusan berdasarkan data, benchmarking dan dukungan dari pimpinan. Oleh karena itu perlu desain perbaikan perkuliahan berkelanjutan, mengingat proses perkuliahan yang berkualitas adalah proses perkuliahan yang berupaya memenuhi harapan para mahasiswa dan membuat mereka puas mengikuti perkuliahan tersebut. Lebih lanjut, untuk memperbaiki kualitas pembelajaran dan interaksi antara mahasiswa dengan dosen, ada beberapa teknik yang dapat diadopsi dari Techniques to Improve Teaching Interaction with Student in the College of Business, The College of Business at Rochester Intitute of Technology (RIT) (Bonvillan \& Nowlin, 1995).

Untuk memjadikan perkuliahan berkualitas bukan berarti dengan perbaikan kurikulum namun pada perkuliahan. Perbaikan perkuliahan yang dimaksud yaitu pengelolaan yang melibatkan mahasiswa mulai dari perencanaan, implementasi hingga pada evaluasi, agar lebih memberikan pengalaman belajar kepada mahasiswa. Evaluasi pembelajaran dalam perkuliahan bukan berupa tes objektif karna tidak mengembangkan kreativtas, sehingga waktu dan biaya tidak menjadi percuma. Untuk memperbaiki kepemimpinan alumni perlu ada perbaikan pembelajaran berbasis kreativitas.

Perlunya dosen yang professional

Untuk dapat mewujudkan perkuliahan yang berbasis pelanggan, diperlukan dosen yang professional. Profesi dosen sesungguhnya menunjuk pada upaya-upaya yang dilakukan oleh tenaga pengajar sebagai pendidik dan pembelajar realisasi dari peran selaku di perguruan tinggi (Arikunto, Suharsimi., 2012). Dengan demikian, pengembangan profesionalisme dosen dapat diartikan usaha yang luas untuk meningkatkan kompetensi, kualitas pembelajaran dan peran akademis tenaga pengajar di perguruan tinggi. Dosen dikatakan sebagai "jantung" perguruan tinggi, sehingga dosen sangat menentukan mutu pendidikan dan lulusan yang dilahirkan perguruan tinggi tersebut, di samping secara umum kualitas perguruan tinggi itu sendiri. Jika para dosennya bermutu tinggi, maka kualitas perguruan tinggi tersebut juga akan tinggi, demikian pula sebaliknya.

Sebaik apapun program pendidikan yang dicanangkan, bila tidak didukung oleh para dosen bermutu tinggi, maka akan berakhir pada hasil yang tidak memuaskan. Hal itu 
Pengaruh Kreativitas dalam Peningkatan Kompetensi Kepemimpinan Alumni ... | Krisma W. Wardani

karena untuk menjalankan program pendidikan yang baik diperlukan para dosen yang juga bermutu baik. Dengan memiliki dosen-dosen yang baik dan bermutu tinggi, perguruan tinggi dapat merumuskan program serta kurikulum termodern untuk menjamin lahirnya lulusan-lulusan yang berprestasi dan berkualitas istimewa (Sudiro, 2010).

Penelitian ini menemukan variabel kreativitas pada kurikulum 2013 berbasis KBK Program Manajemen Pendidikan UKSW Salatiga berpengaruh pada tingkat kepemimpinan alumni; Temuan ini sangat penting bagi manajemen peningkatan mutu pendidikan berbasis perkuliahan yang diampu oleh dosen yang profesional.

\section{SIMPULAN DAN SARAN \\ Simpulan}

Hasil penelitian menunjukkan bahwa sebagian besar alumni memiliki kadar kepemimpinan yang tinggi; Penentu kepemimpinan alumni tersebut adalah Peningkatan kreativitas dalam kegiatan perkuliahan dan professionalisme dosen; Pada penelitian ini besarnya pengaruh kreativitas terhadap kepemimpinan alumni Program Manajemen Pendidikan UKSW Salatiga $=$ $55,20 \%$. Ini berarti variabel kreativitas berpengaruh terhadap kepemimpinan alumni Program Manajemen Pendidikan UKSW Salatiga terdukung data. Temuan ini sangat penting bagi manajemen peningkatan mutu pendidikan melalui perkuliahan berbasis kreativitas yang diampu oleh dosen yang profesional.

\section{Saran}

Dalam perkuliahan dosen menjadi tempat tumpuan pengembangan kreativitas, sehingga perlu merencanakan dan menyusun perkuliahan berbasis pada kreativitas dengan pembelajaran yang berbasis masalah, berpikir kritis, pendekatan kelompok, bukan kegiatan individu dimana tetap arahnya ke kepemimpinan.

\section{DAFTAR PUSTAKA}

Arikunto, Suharsimi. 2012. Evaluasi Program Pendidikan. http://anannur.blogspot.co.id/2012/01/evaluasiprogram-pendidikan-prof-dr.html (diakses tanggal: 20 November 2017).

Bonvillian, G., \& Nowlin, W. (1995). Integrating principles of TQM into teaching and learning. Academic Initiatives in Total Quality for Higher Education por Harry V. Roberts, ASQC Quality Press, Milwaukee, Wisconsin, 95-116.

Dyer, J., Gregersen, H., \& Christensen, C. M. 2011. The innovator's DNA: Mastering the five skills of disruptive innovators. Harvard Business Press.

Entwistle, N. and Ramsden. 1987. Understanding Student Learning. London: CroonHelm.

Faisal Burhanudin. 2012/2013. Faktor Kepemimpinan.

https://www.academia.edu/7119898/

Frost, P.J. 2003. Toxic emotion at work: How compassionate managers handle pain and conflict. Boston: Harvard Business School Press.

Goleman, D., R. Boyatzis, \& McKee. 2003 The New Leaders Transforming, the Art of Leadership into The Science of Result. London: Little Brown.

Handoyo, S. (2011). Pengukuran servant leadership sebagai alternatif kepemimpinan di institusi pendidikan tinggi pada masa perubahan organisasi. Makara Hubs-Asia, 8(3).

Hill, Y., Lomas, L., and MacGregor, J. (2003). Students' Perceptions of quality in higher education. Quality Assurance in Education, 11(1) 15-20

Hughes, R., Ginnett, R., \& Curphy, G. 2002. Leadership: Enhancing the lessons of exsperience. New York: McGraw-Hill Irwin

Jabar, C. S. A., \& Pelanggan, G. S. H. Manajemen Mutu Dalam Pembelajaran Di Perguruan Tinggi. academia.edu 
Kolb, A. Y., \& Kolb, D. A. 2009. Experiential learning theory: A dynamic, holistic approach to management learning, education and development. The SAGE handbook of management learning, education and development, 42-68.

Lusiana, N., Andriyani, R., \& Megasari, M. (2015). Buku ajar metodologi penelitian kebidanan. Yogyakarta: Depublish.

Notohamidjojo, O. 2011. Kreativitas yang bertanggungjawab. Universitas Kristen Satya Wacana

Robbins, Stephen P., 1996. Organizational Behavior : Concept Controversies Applications. Sevent Edition, Diterjemahkan Oleh Dr. Hadyana Pujaatmaka, Perilaku Organisasi : Konsep kontroversi Aplikasi, Jakarta: PT. Prenhallindo.

Rohman, A., \& Lamsuri, M. 2009. Memahami pendidikan \& ilmu pendidikan, Yogyakarta: LaksBang Mediatama bekerja sama dengan Kantor Advokat "Hufron \& Hans Simaela".

Sudiro. Maret 2010. (Online). (https://rumahpendidikan.files.wordpres s.com//makalah-profesionalismedosen.pdf, diakses 27 Pebruari 2015).

Sujiono, Y. N., \& Sujiono, B. (2010). Bermain Kreatif Berbasis Kecerdasan Jamak. Jakarta: Indeks.

Untayana, J. R., \& Harta, I. (2016). Pengembangan perangkat pembelajaran limit berbasis pendekatan saintifik berorientasi prestasi belajar dan kemampuan komunikasi matematika. Jurnal Riset Pendidikan Matematika, 3(1), 45-54.

Wibowo, B., Machfudz, M., \& Sunaryo, H. (2015). Pengaruh Karakteristik Pekerjaan, Motivasi Dan Kepemimpinan Terhadap Kinerja Pegawai di Kantor Imigrasi Kelas I Malang. Warta Ekonomi, 4(2).

Yukl, G. A. 2010. Leadership in organizations. Seventeenth Edition. Upper Saddler River, New Jersey: Pearson Education India. 